\title{
PENGARUH PEMBERIAN MINUMAN KUNYIT ASAM TERHADAP INTENSITAS NYERI MENSTRUASI PADA REMAJA PUTRI
}

\author{
IKA NUR SAPUTRI ${ }^{1}$, DWI HANDAYANI ${ }^{2}$, JURPIA YASARA ${ }^{3}$ \\ 1,2,3 Institut Kesehatan Medistra Lubuk Pakam \\ Jl. Sudirman No 38 Lubuk Pakam \\ e-mail: ikanursaputri@gmail.com
}

DOI : $10.35451 / j k k . v 3 i 1.491$

\begin{abstract}
Every month, a normal woman will experience menstruation or menstruation, which is the shedding of endometrial tissue in the absence of a mature egg fertilized by sperm. Menstruation is a natural and natural event, but in fact many women experience menstrual problems, including menstrual pain or dysmenorrhoea. Dysmenorrhoea is pain in the pelvic area due to menstruation and the production of prostaglandins. Often starts immediately after experiencing the first menstruation (menarche). The cause of pain comes from the uterine muscles. Non-pharmacological management of menstrual pain can be done by administering tamarind drink. This study aims to determine the effect of giving tamarind turmeric drink to the intensity of menstrual pain in young women at SMA Negeri 1 Teluk Mengkudu, Serdang Bedagai Regency in 2020. The research method is quantitative. This type of research is a quasiexperimental design with a one-group pretest-posttest design. The population of the study were 150 students of class $X$ and class XI of SMA Negeri 1 Teluk Mengkudu, Serdang Bedagai Regency. The sample selection used purposive sampling as many as 36 people. The results showed that before being given tamarind turmeric drink, the majority of respondents experienced pain in the moderate pain category as many as 30 people (83.3\%). After being given tamarind drink, the majority of respondents experienced pain in the mild pain category as many as 23 people (63.9\%). Through bivariate analysis using the Wilcoxon sign rank test, the $p$-value was $0.000<0.05$. The conclusion is that there is a difference before and after giving tamarind turmeric drink to the intensity of menstrual pain (dysmenorrhea). It is hoped that schools can provide information to students about the use of tamarind turmeric as a nonpharmacological treatment in reducing menstrual pain.
\end{abstract}

Keywords: Turmeric Acid Extract, Menstrual Pain, Adolescent Girl.

\section{Pendahuluan}

Setiap bulan, wanita akan mengalami menstruasi atau haid yang disebabkan karena meluruhnya jaringan endometrium yang tidak terjadi pembuahan. Haid merupakan proses yang fisiologis sehingga setiap wanita remaja akan mengalami haid setiap bulan. Wanita akan mengalami gangguan haid yang disebut dengan dismenorea (Setyowati, 2018).

Dismenorea adalah nyeri yang dirasakan oleh wanita saat menstruasi karena produksi prostaglandin dan biasanya terjadi didaerah panggul. Dismenorea biasanya terjadi segra setelah mengalami haid pertama (menarche). Semua wanita pasti pernah 
merasakan dismenorea dengan berbagai tingkatan yang ditandai dengan adanya nyeri pada daerah panggul dan perut dan terjadi di hari pertama sampai kedua saat menstruasi (Proverawati \& Misaroh, 2015).

Ada beberapa kalangan yang menganggap nyeri menstruasi adalah hal yang biasa, namun ada beberapa perempuan mengalami nyeri menstruasi samapi hari ke 5 menstruasi. Dismenorea mengeakibatkan wanita tidak bisa beraktivitas apapun selama haid karena rasa nyeri bukan main dan tidak tertahankan (Anugoro \& Wulandari, 2017)

Menurut data WHO wanita yang mengalami dismenorea sebesar 1.769 .425 jiwa (90\%), $10-15 \%$ diantaranya mengalami dismenorea berat. Hal ini didukung dengan laporan kasus dismenorea primer disetiap negara lebih dari 50\% (WHO, 2014). Angka kejadian perempuan di setiap negara mengalami dismenorea di dunia sangat besar dengan rata-rata lebih dari $50 \%$. Prevalensi dismenorea di Amerika Serikat sekitar 45-90\%. Dismenorea menyebabkan wanita absen pada saat bekerja dan sekolah dimana sebanyak $13-51 \%$ perempuan telah absen sedikitnya sekali dan $5-14 \%$ berulang kali absen. Studi epidemiologi pada populasi remaja di Amerika Serikat, melaporkan prevalensi dismenorea $59,7 \%$. Responden yang mengeluh nyeri berat $12 \%$, nyeri sedang $37 \%$ dan nyeri ringan $49 \%$ sehingga $14 \%$ remaja putri sering tidak masuk sekolah (Anugoro \& Wulandari, 2017)

Angka kejadian dismenorea pada remaja di Asia adalah 74.5\%. Pada remaja putri hispanic prevalensi dismenorea sebesar 85\%. Sedangkan angka kejadian di Indonesia adalah $55 \%$. Melihat data tersebut dapat diartikan bahwa hampir semua wanita pernah mengalami dismenorea (Setyowati, 2018).
Dismenorea juga memberikan dampak yang buruk bagi remaja putri, yaitu menimbulkan gangguan dalam kegiatan belajar mengajar, tidak memperhatikan penjelasan yang diberikan oleh guru, dan kecenderungan tidur di kelas saat kegiatan belajar mengajar. Ini berpengaruh pada prestasi dibidang akademik maupun non akademik. Banyak remaja yang mengeluh bahkan tidak mau masuk sekolah pada saat menstruasi. Semakin berat derajat nyeri yang dialami maka aktivitas belajarnya pun semakin terganggu (Iswari, Surianti, \& Mastini, 2014).

Selama ini penanganan dysmenorrhea dilakukan secara farmakologis dan non-farmakologis. Secara farmakologis menggunakan obat-obatan anti nyeri dan obat golongan non steroid anti prostagalndin (Anugoro \& Wulandari, 2017). Secara tradisional (non farmakologis) ada beberapa cara yang dilakukan misal melakukan kompres hangat, senam yoga, massage, istirahat dan minum tanaman herbal seperti kunyit (Purwanto, 2013).

Kandungan kunyit sebagai anti nyeri dan kandungan asam jawa obatobatan golongan anti prostalglandin non steroid sehingga peneliti menggabungkan kunyit dan asam sebagai minuman untuk menurunkan nyeri menstruasi. Hasil penelitian Marsaid, et al (2017) bahwa minuman kunyit asam sangat efektif untuk menurunkan dismenorea. Menurut Jurnal Penelitian (Naldi, 2018), bahwa remaja putri yang mengkonsumsi minuman kunyit asam selama 3 bulan dapat menurunkan nyeri menstruasi.

Survei awal yang dilakukan terhadap 10 siswi yang diambil secara acak dari kelas $X$. Dari 10 orang siswi tersebut, 8 diantaranya mengalami nyeri menstruasi, rata-rata nyeri yang dialami remaja putri tersebut adalah 
nyeri di bagian perut dan punggung bawah, lebih cenderung malas-malasan dan memilih istirahat ketika nyeri yang dirasakan begitu berat, sehingga mengharuskan mereka untuk mengkonsumsi obat-obatan sebagai penghilang nyeri. Hasil wawancara kepada salah satu guru mengatakan sekitar 7-8 orang tiap bulan yang berhalangan hadir karena nyeri menstruasi dan ada juga yang izin pulang akibat nyeri menstruasi. Dari data UKS juga diperoleh bahwa siswi yang mengalami nyeri menstruasi sering beristirahat di ruang UKS dan tidak mengikuti pelajaran di kelasnya.

\section{METODE}

Jenis penelitian ini adalah penelitian kuantitatif dalam bentuk Quasi eksperiment. Desain penelitian ini adalah one-group pretest-posttest design. Dalam rancangan ini, terdapat pretest, sebelum diberi perlakuan. Populasi penelitian ini adalah siswi kelas $X$ dan kelas XI SMA Negeri 1 Teluk Mengkudu Kabupaten Serdang Bedagai sebanyak 150 orang. Sampel yang digunakan menggunakan teknik purposive sampling dengan jumlah sampel sebanyak 36 orang. Analisa data dilakukan dengan uji statistik Wilcoxon Test.

\section{HASIL}

1. Sebelum Pemberian Kunyit Asam

Tabel 1 Distribusi Frekuensi Intensitas Nyeri Menstruasi pada Remaja Putri Sebelum Dilakukan Pemberian Minuman Kunyit Asam

\begin{tabular}{|c|c|c|c|c|c|}
\hline No & $\begin{array}{c}\text { Intensitas } \\
\text { Nyeri }\end{array}$ & $\mathrm{F}$ & $\%$ & Mean & $\begin{array}{c}\text { Standa } \\
r \\
\text { Devias } \\
i \\
\end{array}$ \\
\hline 1 & Ringan & 1 & 2,8 & & \\
\hline 2 & Sedang & 30 & 83,3 & 5,8889 & 1,23700 \\
\hline \multirow[t]{2}{*}{3} & Berat & 5 & 13,9 & & \\
\hline & Total & 36 & 100,0 & & \\
\hline
\end{tabular}

terlihat bahwa mayoritas responden mengalami nyeri pada kategori nyeri sedang sebanyak 30 orang (83,3\%) dan minoritas mengalami nyeri pada kategori nyeri ringan sebanyak 1 orang $(2,8 \%)$ dengan nilai mean sebesar 5,8889 dengan standar deviasi 1,23700.

\section{Sesudah Pemberian Kunyit Asam}

Tabel 2 Distribusi Frekuensi Intensitas Nyeri Menstruasi pada Remaja Putri Sesudah Dilakukan Pemberian Minuman Kunyit Asam

\begin{tabular}{cccccc}
\hline No & $\begin{array}{c}\text { Intensitas } \\
\text { Nyeri }\end{array}$ & $\mathrm{F}$ & $\%$ & Mean & $\begin{array}{c}\text { Standar } \\
\text { Deviasi }\end{array}$ \\
\hline 1 & Ringan & 23 & 63,9 & & \\
2 & Sedang & 13 & 36,1 & 3,4167 & 0,60356 \\
3 & Berat & 0 & 0,0 & & \\
\hline & Total & 36 & 100,0 & & \\
\hline
\end{tabular}

Berdasarkan tabel di atas,
terlihat mayoritas responden
mengalami nyeri ringan sebanyak 23 orang $(63,9 \%)$ dan minoritas mengalami nyeri sedang sebanyak 13 orang $(36,1 \%)$ dengan nilai mean sebesar 3,4167 dengan standar deviasi 0,60356 .

Berdasarkan uji Saphiro Wilk diketahui bahwa sebaran data tidak normal. Hal ini terlihat dari nilai Sig. = 0,013 untuk data pretest dan 0,000 untuk data posttest $(<0,05)$. Dapat disimpulkan bahwa nilai significancy $<$ a $(0,05)$ maka distribusi pada data tersebut tidak normal, sehingga dilanjutkan dengan uji Wilcoxon Test.

3. Perbedaan Sebelum dan Sesudah

Tabel 3

\section{Distribusi Perbedaan Intensitas Nyeri Menstruasi Sebelum dan Sesudah Pemberian Minuman Kunyit Asam}

\begin{tabular}{cccccccc}
\hline No & Kelompok & Mean & $S D$ & Median & Min & Max & $P$-Value \\
\hline 1 & Sebelum & 5,8889 & 1,23700 & 6,0000 & 3,00 & 8,00 & \multirow{2}{*}{0,000} \\
2 & Sesudah & 3,4167 & 0,60356 & 3,0000 & 3,00 & 5,00 & \\
\hline
\end{tabular}

Berdasarkan tabel diatas bahwa rerata nyeri menstruasi sebelum diberikan minuman kunyit asam sebesar 
5,8889 dan sesudah diberikan minuman kunyit asam sebesar 3,4176. Hasil uji statistik didapatkan hasil $p$-value 0,000 $<0,05$ artinya ada perbedaan sebelum dan sesudah pemberian minuman kunyit asam terhadap intensitas nyeri menstruasi (dysmenorrhea) pada remaja putri.

\section{PEMBAHASAN}

Penelitian yang telah dilakukan bahwa $83,3 \%$ responden mengalami nyeri sedang. Hal ini sesuai dengan penelitian Suri (2014) bahwa responden mengalami nyeri sedang. Remaja putri pada saat menstruasi sering mengalami nyeri menstruasi sedang sehingga mengakibatkan gangguan pada proses belajar mengajar, gangguan istirahat dan aktivitas lainnya. Selain itu, beberapa faktor seperti stress, ansietas, usia, lingkungan yang bising, dan pengalaman nyeri sebelumnya juga mempengaruhi nyeri menstruasi. Persepsi seseorang yang bersifat subjektif mengakibatkan respon nyeri yang bervariasi.

Menurut Hamdayani (2018) bahwa sebelum diberikan minuman kunyit asam rerata nyeri sebesar 5,20, dengan nilai standar deviasi 1,619. Hal ini terjadi karena pada awal menstruasi prostaglandin meningkat sehingga terjadi kontraksi yang kuat pada myometrium dan pembuluh darah menjadi sempit, terjadi iskemia pada endometrium, perdarahan, dan nyeri.

Hasil penelitian ini terjadi penurunan intensitas nyeri menstruasi sehingga bisa melaksanakan aktivitas seperti biasa. Jika dilihat dari skala nyeri menstruasi, ada 23 orang yang memilih pada skala nyeri 3 , terdapat 11 orang yang memilih pada skala nyeri 4 dan hanya 2 orang yang memilih pada skala nyeri 5. Jika dilihat sebelum dan sesudah, terdapat perubahan skala nyeri berat menjadi sedang dan skala nyeri sedang menjadi ringan.
Namun dalam penelitian ini, ditemukan responden yang memiliki skala nyeri sedang sebelum diberikan minuman kunyit asam dan tidak terjadi penurunan nyeri setelah diberikan minuman kunyit asam. Hal ini mungkin minuman kunyit yang diberikan tidak begitu berpengaruh terhadap nyeri menstruasi yang dialami. Selain itu, responden hanya minum 2 kali dari serbuk kunyit yang diberikan karena alasan responden tidak begitu menyukai minuman-minuman herbal.

Hasil penelitian ini sejalan dengan hasil penelitian yang dilakukan oleh Suri (2014) bahwa minuman kunyit dapat menurunkan tingkat nyeri menstruasi pada remaja putri. Hal ini disebabkan karena kunyit memiliki bahan aktif alami yang bisa menurunkan reaksi inflamasi dan menekan terjadinya kontraksi yang berlebihan serta mengurangi stress emosional yang bekerja melalui system saraf otonom. Hal ini sesuai dengan yang dikemukakan oleh Marsaid, et.all (2017) bahwa kunyit asam mengandung curcumin, minyak atsiri, anthocyanin, dan tannin yang berfungsi untuk memblok produksi F2a sehingga prostaglandin menurun yang menyebabkan nyeri menstruasi berkurang.

Menurut jurnal penelitian Widiatami (2018), minum kunyit asam sudah menjadi kebiasaan masyarakat yang brkhasiat untuk menurunkan nyeri menstruasi. Pada era modern sekarang remaja putri lebih memilih produk herbal seperti kunyit asam. Minuman kunyit asam dibuat dari kunyit dan asam sebagai bahan utama. Kunyit dan asam jawa mengandung bahan aktif antipiretika, analgetik dan antiinflamasi. Hasil penelitian menunjukkan bahwa nilai $p$-value $0,000<0,05$. Maka dapat disimpulkan ada perbedaan sebelum dan sesudah pemberian minuman kunyit asam terhadap intensitas nyeri menstruasi 
(dysmenorrhea) pada remaja putri.Hal ini sesuai dengan penelitian Suri (2014), Jamila (2018), Marsaid, et al (2017), dan Hamdayani (2018) bahwa terdapat pengaruh minuman kunyit asam terhadap penurunan nyeri menstruasi.

Menurut asumsi peneliti bahwa kandungan curcumin dan minyak atsiri pada kunyit, kombinasi anthocyanin dan tanin pada asam jawa memiliki cara kerja menghambat produksi prostaglandin sehingga nyeri menstruasi berkurang.

Menurut Hartati (2013) dan Marsaid et all (2017) kunyit memiliki kandungan curcumin dan minyak atsiri yang berperan sebagai antioksidan, antitumor, dan antikanker. Selain itu reaksi COX (cyclooxygenase) terhambat sehingga kontraksi uterus berkurang. Asam jawa mengandung anthocyanin dan tanin yang berfungsi mengurangi ketegangan otot sehingga dapat menurunkan kram otot pada miometrium saat menstruasi (Proverawati \& Misaroh, 2015).

\section{KESIMPULAN}

a. Intentitas nyeri menstruasi pada remaja putri sebelum diberikan minuman kunyit asam mayoritas adalah kategori nyeri sedang sebanyak 30 orang $(83,3 \%)$.

b. Intentitas nyeri menstruasi pada remaja putri sesudah diberikan minuman kunyit asam, mayoritas mengalami nyeri menstruasi ringan sebanyak 23 orang (63,9\%).

c. Ada pengaruh minuman kunyit asam terhadap intensitas nyeri menstruasi pada remaja putri dengan nilai $p$-value $=0,000$ $(<0,05)$.

\section{DAFTAR PUSTAKA}

Anurogo, D., dan Wulandari, A. 2017. Cara Jitu Mengatasi Nyeri Haid. Yogyakarta: ANDI
Hartati SY, Balittro. 2013. Khasiat Kunyit Sebagai Obat Tradisional Dan Manfaat Lainnya. WPPTI. 19(2):6-9

Iswari, D. P., Kadek., Surianti, I. D. A. K., \& Mastini, G. A. A. P. 2014. Hubungan Dismenore dengan Aktivitas Belajar Mahasiswi PSIK FK UNUD tahun 2014. Community of Publishing in Nursing 2(3)

Jamila, F. 2018. Pengaruh Pemberian Minuman Kunyit Asam Terhadap Penurunan Tingkat Nyeri Menstruasi (Dysmenorrhea) Primer pada Remaja Putri di MTs Nurul Hikmah Kota Surabaya Tahun 2018 . Jurnal Penelitian Infokes : Info Kesehatan P-ISSN : 2087-877X, E-ISSN : 26552213 Vol. 8, No. 2, Juli 2018

Hamdayani, D. 2018. Pengaruh Pemberian Minuman Kunyit Asam Terhadap Penurunan Dismenore Primer Pada Mahasiswi Tingkat II Prodi S1 Keperawatan STIKES Mercubaktijaya Padang. Jurnal MENARA Ilmu Vol. XII Jilid II No.80 Februari 2018. ISSN 1693-2617 E-ISSN 2528-7613

Marsaid; Nurjayanti; Rimbaga, Yocykha, Ari. 2017. Efektifitas pemberian ekstrak kunyit asam terhadap penurunan dismenore pada remaja putri di desa tambang Kecamatan Pudak Kabupaten Ponorogo. Jurnal. Global Health Science. Vol. 2. Ponorogo

Naldi, Tri. 2018. Efektivitas Pemberian Minuman Rebusan Kunyit Asam Untuk Mengurangi Nyeri Haid Pada Remaja Putri Di Pondok Pesantren Bustanul Muttaqin Suban, Lampung Selatan Tahun 2017. Fakultas Pertanian Universitas Lampung Bandar Lampung 2018.

Purwanto, Budhi. 2013. Herbal dan Keperatan Komplementer (Teori, Praktik, Hukum dalam Asuhan Keperawatan). Yogyakarta : Nuha Medika.

Proverawati, A., dan Misaroh, S. 2014. Menarche Menstruasi Pertama 
Received: 30 September 2020 :: Accepted: 17 0ktober 2020 :: Published: 31 Oktober 2020

Penuh Makna. Yogyakarta: Nuha Medika

Setyowati, H. 2018. Akupresur Untuk Kesehatan Wanita Berbasis Hasil Penelitian. Magelang: Unimma Press

Suri, S.I. 2014. Pengaruh Minuman Kunyit Terhadap Penurunan Tingkat Nyeri Menstruasi Pada Remaja Putri Kelas 1 Di Pondok Pesantren Nurul Yaqin Pakandangan Kecamatan 6 Lingkung Kabupaten Padang Pariaman Tahun 2014. Jurnal Penelitian.

Widiatami, D. 2018. Study Literature Tentang Pemberian Minuman Kunyit Asam Terhadap Tingkat Nyeri Menstruasi Pada Remaja Putri. Jurnal Kebidanan Vol. 8 No. 2 October 2018 p- ISSN.20897669 e-ISSN. 2621-2870

WHO.2014.Disminoreahttp://www. who .int/gho/mdg/poverty_hunger/d isminorea_text/en/index.html. Diakses Pada Tanggal 20 Februari 2018 